\title{
Osobliwości przekształceń strukturalnych w strefie wpływu ciepła złączy spawanych MAG stali wysokowytrzymałej WELDOX 1300
}

\author{
Features of structural transformation in metals HAZ high- \\ strength steel WELDOX 1300 performed by MAG welding
}

\section{Streszczenie}

W artykule przedstawiono wyniki badań właściwości struktury w metalu strefy wpływu ciepła stali konstrukcyjnej wysokowytrzymałej typu WELDOX 1300 wykonane metodą MAG. Opracowano wykresy CTPC-s, ustalono i opisano przyczyny obniżenia właściwości mechanicznych połączeń spawanych stali WELDOX 1300.

Słowa kluczowe: spawanie MAG, mikrostruktura, bainit, martenzyt, pęknięcia zimne, Weldox

\section{Abstract}

The article studied the features of the formation of structure in the HAZ metal high-strength structural steel WELDOX 1300, made by MAG welding, built thermokinetic diagram decomposition of austenite (CCT diagram) and installed reason for the decline of the mechanical properties of welded joints in steel WELDOX 1300.

Keywords: MAG welding, microstructure, Weldox, cold cracks

\section{Wstęp}

Jednym z głównych problemów rozwoju współczesnej budowy maszyn jest poprawa wskaźników techniczno-ekonomicznych maszyn, mechanizmów i konstrukcji inżynierskich polegająca na obniżenia ich materiałochłonności, podwyższenia bezpieczeństwa eksploatacji i trwałości. W rozwiązaniu tego problemu ważną rolę mogą odegrać nowe stale konstrukcyjne wysokowytrzymałe (Re>1000 MPa).

Zapotrzebowanie na stal z wysokimi wskaźnikami wytrzymałościowymi do pewnego stopnia jest związana z wytwarzaniem konstrukcji lądowych oraz pojazdów dużej ładowności. W Ukrainie przedstawicielami stali wysokowytrzymałych są gatunki 12KhGN3MAFD i 15KhGN2MAFJuCz.

Szwedzka firma SSAB jest wiodąncym na świecie producentem wysokowytrzymałych stali konstrukcyjnych. SSAB produkuje do $6 \mathrm{mln}$ ton stali rocznie, z których około 38\% stanowią stale wysokowytrzymale występujące pod marką HARDOX, WELDOX, ARMOX I TOOLOX, charakteryzujące się poziomem wytrzymalosci od 450 do $1700 \mathrm{MPa}$.

Stale grupy WELDOX znajdują szerokie zastosowanie w różnych branżach przemysłu np. w urządzeniach dźwigowych (rys. 1a) (WELDOX 355), w technice szynowej (WELDOX 420), sprzęcie górniczym (WELDOX 500), w produkcji samobieżnych pojazdów dużej ładowności (WELDOX 900, 960), mobilnych mostów (WELDOX 1100) (rys. 1b). [1]

Powszechne stosowanie nowych stali WELDOX w budowie maszyn i budownictwie jest utrudnione przez ich stosunkowo ograniczoną spawalność. Newralgicznym elementem
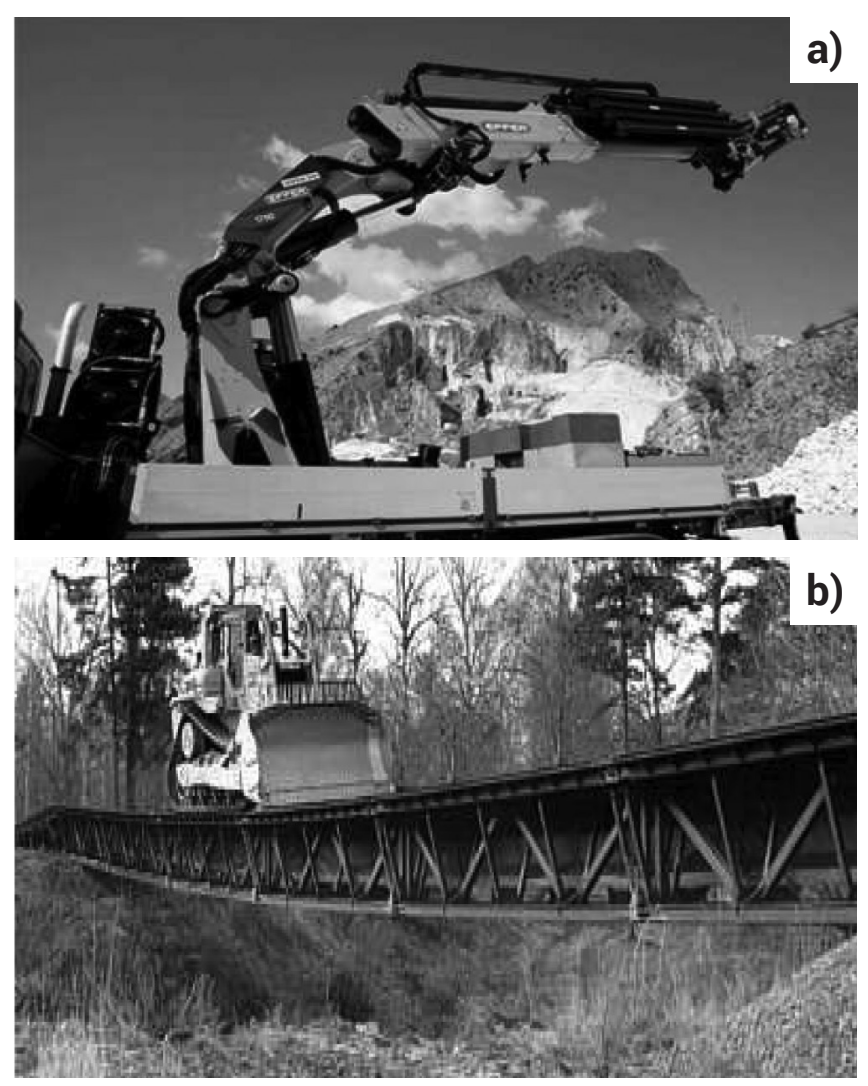

Rys. 1. Wykorzystanie stali WELDOX w przemyślee [1]

Fig. 1. Using steel WELDOX in the industry [1]

Prof. dr hab. inż. Gieorgij M. Grigorenko, dr inż. Walery A. Kostin, dr inz. Walery D. Poznjakow, dr inż. Sergey L. Żdanow, mgr inż. Wiktor W. Żukow - E. O. Paton Electric Welding Institute of the National Academy of Sciences of Ukraine. 
w połączeniach spawanych stali wysokowytrzymałych jest strefa wpływu ciepła (SWC), ponieważ pod wpływem cyklu cieplnego spawania, struktura i właściwości metalu w SWC mogą podlegać istotnym zmianom polegającym na rozroście ziarna i częściowemu zahartowaniu, co w istotnym stopniu wpływa na szereg właściwości mechanicznych złącza w tym: udarność, plastyczność, wydłużenie. W literaturze, informacje o właściwościach i przemianach strukturalnych w SWC stali WELDOX 1300 są nieliczne i nieusystematyzowane [1-4]. Celem niniejszej pracy jest scharakteryzowanie struktury materiały rodzimego oraz SWC $w$ stali WELDOX 1300 w kontekście wykresów CTPC-s, a w konsekwencji ustalenie właściwych warunków technologicznych spawania z punktu widzenia właściwości złączy spawanych.

W badaniach zastosowano stal WELDOX 1300 o grubości $10 \mathrm{~mm}$ (według certyfikatu WELDOX 1300 UK Special Data Sheet: 2005-10-15), materiał dodatkowy - drut proszkowy MEGAFIL - 1100M.

Równoważnik węgla stali WELDOX 1300 wynosi odpowiednio: CET $(\mathrm{CEV})=0,43 \%(0,67 \%)$. Właściwości mechaniczne stali WELDOX 1300 i stopiwa złącza wykonanego zmechanizowanym spawaniem MAG w środowisku gazu ochronnego M21 (82/18) drutem elektrodowym MEGAFIL - $1100 \mathrm{M}$ przedstawiono w tablica II.

Tablica II. Właściwości mechaniczne stali WELDOX 1300 i stopiwa Table II. The mechanical properties of the steel WELDOX 1300 and weld metal

\begin{tabular}{|c|c|c|c|c|c|c|}
\hline \multirow[t]{2}{*}{ Obiekt } & \multirow[t]{2}{*}{$\begin{array}{c}\mathrm{R}_{0,2} \\
\mathrm{MPa}\end{array}$} & \multirow[t]{2}{*}{$\begin{array}{c}\mathrm{R}_{\mathrm{z}} \\
\mathrm{MPa}\end{array}$} & \multirow[t]{2}{*}{$\begin{array}{l}\mathrm{A}_{5} \\
\%\end{array}$} & \multirow[t]{2}{*}{$\begin{array}{l}Z \\
\%\end{array}$} & \multicolumn{2}{|c|}{$\begin{array}{c}\mathrm{KV}, \mathrm{J} \text { w } \\
\text { temperaturze } \\
{ }^{\circ} \mathrm{C}\end{array}$} \\
\hline & & & & & -40 & -60 \\
\hline $\begin{array}{l}\text { WELDOX } \\
1300 \\
\text { (UK_Spe- } \\
\text { cial Data) }\end{array}$ & 1300 & 1700 & 8 & 37,9 & 27 & 27 \\
\hline WELDOX & 1157 & 1605 & 16,0 & 61,2 & & \\
\hline 1300 & 1205 & 1604 & 15,6 & 61,4 & 33 & - \\
\hline SWC & 1253 & 1602 & 14,6 & 60,5 & & \\
\hline & $818 *$ & $1047^{*}$ & $13,3^{*}$ & $43,7^{*}$ & & \\
\hline Stopiwo & $763 *$ & 1009* & $10,0 *$ & $46,2^{*}$ & $21 * *$ & - \\
\hline & 801 ** & $953^{* \star}$ & $3,7 *$ & $9,8 * *$ & & \\
\hline \multicolumn{7}{|c|}{$\begin{array}{l}\text { * - próbę przeprowadzono z wstępnym podgrzewaniem } \\
\text { do temperatury } 150^{\circ} \mathrm{C} \text {. } \\
\text { ** - próbę przeprowadzono z wstępnym podgrzewaniem } \\
\text { do temperatury } 120^{\circ} \mathrm{C} \text {. }\end{array}$} \\
\hline
\end{tabular}

Analiza właściwości mechanicznych wskazuje (tabl. II), że granica plastyczności ( 1200 MPa) i doraźna wytrzymałość na rozciąganie ( 1600 MPa) badanej stali WELDOX 1300 w są o blisko 100 MPa niższe niż wartości nominalne poświadczone w ateście, w efekcie czego naturalnie wydłużenie, przewężenie i udarność mają wyższe wartości.

Mikrostruktura materiału rodzimego stali WELDOX 1300 ma charakter bainityczno-martenzytyczny (rys. 2), składa się z około $60 \%$ bainitu resztę stanowi martenzyt. Twardość zawiera się w zakresie od 378 do 388 HV1.

Do scharakteryzowania osobliwości mikrostruktury materiału rodzimego stali WELDOX 1300 zastosowano mikrosondę
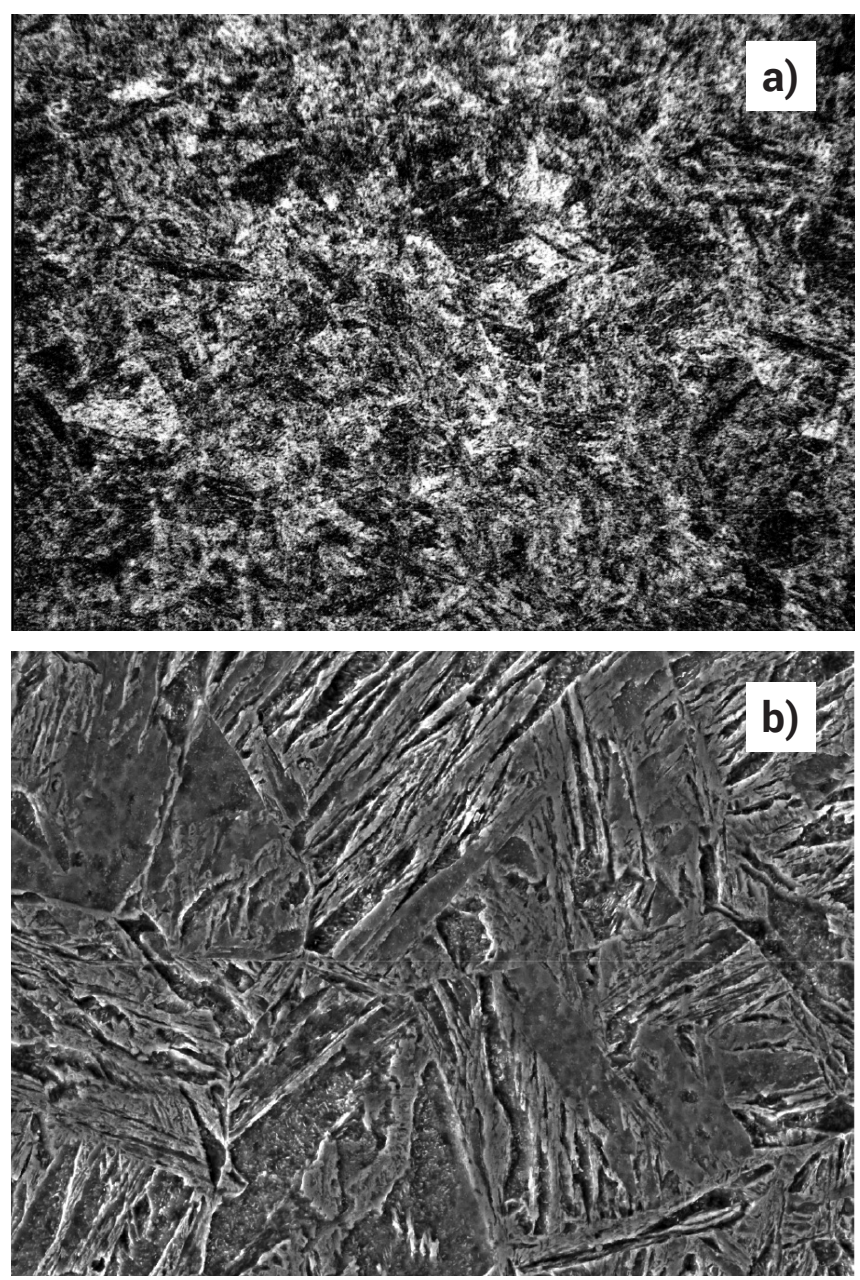

Rys. 2. Mikrostruktura materiału rodzimego stali WELDOX 1300 : a) mikroskopia optyczna (x500); b) mikroskopia skaningowa (x5000) Fig. 2. Microstructure of steel WELDOX 1300 in the initial state: a) light microscopy (x500), b) scanning microscopy JAMP-9500F (x5000)

Tablica I. Skład chemiczny stali WELDOX-1300 wg normy oraz skład zastosowanego do badań wytopu, skład chemiczny drutu proszkowego MEGAFIL-1100M oraz stopiwa

Table I. The chemical composition of the steel WELDOX-1300, cored wire MEGAFIL-1100M and the weld metal

\begin{tabular}{|c|c|c|c|c|c|c|c|c|c|c|}
\hline \multirow{2}{*}{ Obiekt badania } & \multicolumn{10}{|c|}{ Zawartość pierwiastków, \% wag. } \\
\hline & C & $\mathrm{Si}$ & $\mathrm{Mn}$ & $\mathrm{Cr}$ & $\mathrm{Ti}$ & $\mathrm{Ni}$ & Mo & $\mathrm{Nb}$ & V & $\mathrm{Cu}$ \\
\hline $\begin{array}{c}\text { Stal WELDOX } \\
1300 \text { (wegług normy) }\end{array}$ & 0,25 & 0,50 & 1,40 & 0,80 & 0,02 & 2,0 & 0,70 & 0,04 & 0,08 & 0,10 \\
\hline $\begin{array}{l}\text { Stal WELDOX } 1300 \\
\text { (badany wytop) }\end{array}$ & 0,241 & 0,204 & 0,92 & 0,48 & 0,004 & 1,27 & 0,35 & 0,021 & 0,02 & 0,02 \\
\hline $\begin{array}{c}\text { Drut elektrodowy proszkowy } \\
\text { MEGAFIL - } 1100 \mathrm{M}\end{array}$ & 0,07 & 0,05 & 1,50 & 0,80 & - & 2,7 & 0,80 & - & - & - \\
\hline Stopiwo & 0,241 & 0,204 & 0,92 & 0,48 & 0,01 & 1,27 & 0,35 & 0,02 & 0,02 & 0,02 \\
\hline
\end{tabular}


JAMP 9500F z polową katodą emisyjną wysokiej rozdzielczości. Ustalono, że wyjściowa struktura stali WELDOX 1300 składa się z równomiernie rozłożonych $\mathrm{w}$ objętości ziaren bainitu i martenzytu (rys. 2b) z dużą ilością wydzieleń wysokodyspersyjnych węglikoazotków wewnątrz ziaren. Bainit zlokalizowany jest głównie w obrębie granic ziaren, podczas gdy martenzyt przeważnie w centralnej części krystalitów. Równomierne rozproszenie węglikoazotków (rys. 3a) w objętości igieł dolnego bainitu sprzyja współistnieniu zarówno dobrych właściwości wytrzymałościowych i plastycznych.

Ustalono, że węglikoazotki mają przeważnie igiełkowatą budowę (rys. 3b), rozmiar igieł mieści się w zakresie 50 $\div 100$ $\mathrm{nm}$. Dane analizy rentgenowskiej wskazują, że w materiale rodzimym stali WELDOX 1300 formują się węgliki żelaza $\mathrm{Fe}_{3} \mathrm{C}$ (w ilości około 0,52\%), węglikoazotki niobu $\mathrm{Nb}(\mathrm{Z}, \mathrm{N}$ ) i tytanu Ti(C, N) $(0,04 \%)$, azotek glinu AIN $(0,01 \%)$ i azotek boru $\mathrm{BN}(0,01 \%)$.
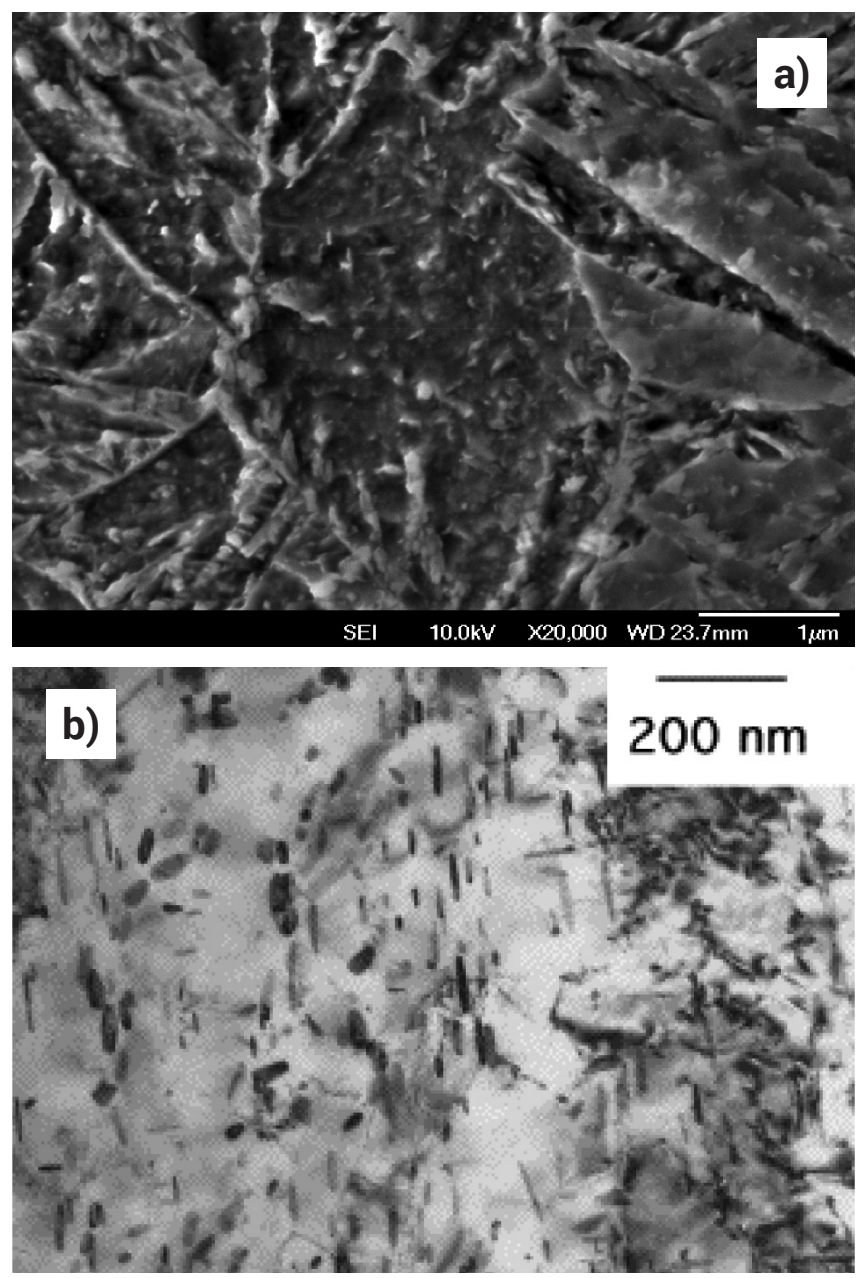

Rys. 3. charakter rozmieszczenia węglikoazotków w stali WELDOX 1300: a) mikorsonda JAMP 9500F x20000; b) mikroskop transmisyjny JEM 200CX x 100000

Fig. 3. Distribution of carbonitrides in steel WELDOX 1300: a) microprobe JAMP 9500F $\times 20000$; b) transmission microscope JEM $200 C X \times 100000$

Do wyznaczenia optymalnej prędkości stygnięcia złącza podczas spawania stali WELDOX 1300 był wykorzystany system symulacji cykli termiczno-odkształceniowych spawania Gleeble 3800 , przeprowadzono badania dylatometryczne i zbadano charakter przemian austenitu w stali WELDOX 1300. Podczas badań prędkość chłodzenia metalu (V6/5) zawierała się $\mathrm{w}$ przedziale od 1,3 do $63,0{ }^{\circ} \mathrm{C} / \mathrm{s}$ w zakresie temperatury od 600 do $500^{\circ} \mathrm{C}$, co odpowiada warunkom łukowego spawania stali wysokowytrzymałych.

Według wyników analizy dylatometrycznej i metalograficznej przebadanych na symulatorze próbek, został zbudowany wykres CTPc-S przemian austenitu stali WELDOX 1300 (rys. 4).
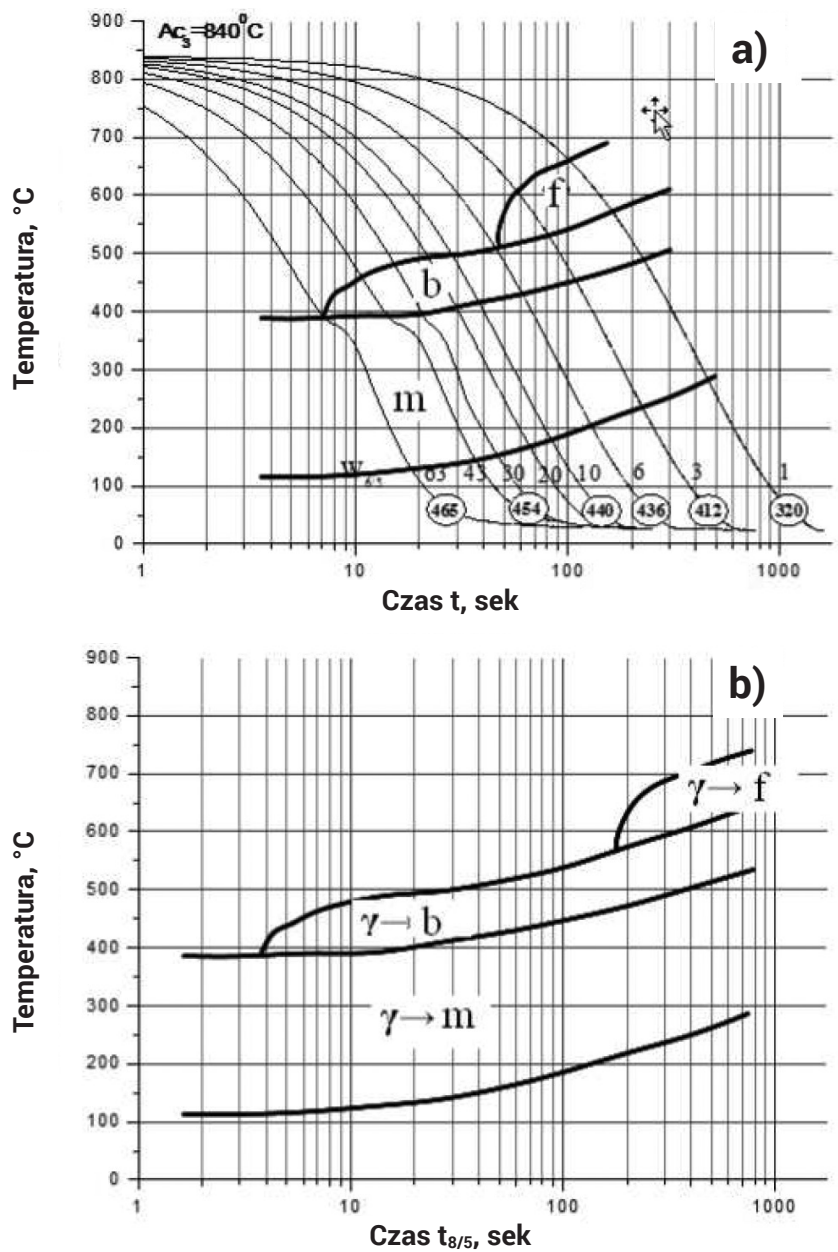

Rys. 4. Wykres CTPC-s przemian austenitu stali WELDOX 1300 : a) tradycyjny; b) we współrzędnych temperatura-czas $t_{8 / 5}$ [4]

Fig. 4. CCT diagram steel WELDOX 1300: a) traditional, b) in coordinates temperature - time cooling $\mathrm{t}_{8 / 5}[4]$

Przemiana austenitu w zbadanym zakresie prędkości chłodzenia odbywa się w zakresie: ferrytycznej, bainitycznej i martenzytycnej (rys. 4a). Przy małej prędkości chłodzenie od 1,3 do $6,0^{\circ} \mathrm{C} / \mathrm{s}$ w metalu SWC stali WELDOX 1300 mają miejsce przemiany: ferrytyczna (f), bainitnyczna (b) i martenzytyczna $(\mathrm{m})$. Stopowanie roztworu stałego molibdenem (0.8\%) i niklem (2.0\%) sprzyja trwałości austenitu, wskutek czego, temperatura początku przemiany ferrytycznej (przy prędkości chłodzenie $3 \div 5^{\circ} \mathrm{C} / \mathrm{s}$ w tej stali osiąga skrajnie niskie wartości $\left(610 \div 550{ }^{\circ} \mathrm{C}\right)$.

Wraz ze zwiększeniem prędkości chłodzenia ilość ferrytu stopniowo obniża się i przy $6^{\circ} \mathrm{C} / \mathrm{s}$ zanika zupełnie, struktura składa się wtedy z bainitu i martenzytu.

Późniejsze zwiększenie prędkości chłodzenia do $63^{\circ} \mathrm{C} / \mathrm{s}$ sprzyja intensywnej przemianie martenzytycznej kosztem bainitu.W całym zakresie prędkości chłodzenia (V6/5 1,3 $-63,0^{\circ} \mathrm{C} / \mathrm{s}$ ) temperatura początku (Ms) i końca (Mf) przemiany austenitycznej stopniowo obniża się, przy czym, temperatura początku przemiany obniża się w mniejszym stopniu, (z $520^{\circ} \mathrm{C}$ do $\left.390^{\circ} \mathrm{C}\right)$, a temperatura końca przemiany $\left(\mathrm{z} 290^{\circ} \mathrm{C}\right.$ do $\left.110^{\circ} \mathrm{C}\right)$ (rys. 4b). Twardość próbek zwiększa się z 320 do $465 \mathrm{HV} 1$.

Przy wysokiej prędkości chłodzenia (V6/5>63 $\left.{ }^{\circ} \mathrm{C} / \mathrm{s}\right)$ powstaje struktura czysto martenzytyczna, a temperatura początku i końca przemian strukturalnych i twardość zostają praktycznie na niezmienionym poziomie. Z podwyższeniem prędkości chłodzenia stali WELDOX 1300 temperatura początkui końca przemianybainityczno-martenzycznejzmienia się odpowiednio w zakresie temperatury od 610 do $290^{\circ} \mathrm{C}$ i od 490 do $130{ }^{\circ} \mathrm{C}$ i prowadzi do zwiększenia w nim zawartość martenzytu z około 35\% do nawet 95\%. Dla tej stali charakterystyczne jest zupełne zakończenie procesu przemiany austenitu - nie powstaje austenit szczątkowy. 
Podwyższona zawartość elementów stopowych w stali WELDOX 1300 prowadzi do zauważalnego wzrostu temperatury początku przemimany martenzytycznej od 520 do $390^{\circ} \mathrm{C}$ (rys. 4 b). Skonfrontowanie obliczonej wartości temperatury początku przemiany martenzytycznej $\mathrm{Ms}=480{ }^{\circ} \mathrm{C}$, zgodnie z równaniem (1) [5] z eksperymentalnymi danymi pokazało stosunkowo dużą zgodność w zakresie niskiej prędkości chłodzenia.

$\mathrm{M}_{\mathrm{s}}\left({ }^{\circ} \mathrm{C}\right)=650-361 \mathrm{C}-39 \mathrm{Mn}-35 \mathrm{~V}-20 \mathrm{Cr}-17 \mathrm{Ni}-10 \mathrm{Cu}-5 \mathrm{Mo}-$ $5 \mathrm{~W}+16 \mathrm{Co}+30 \mathrm{Al}$
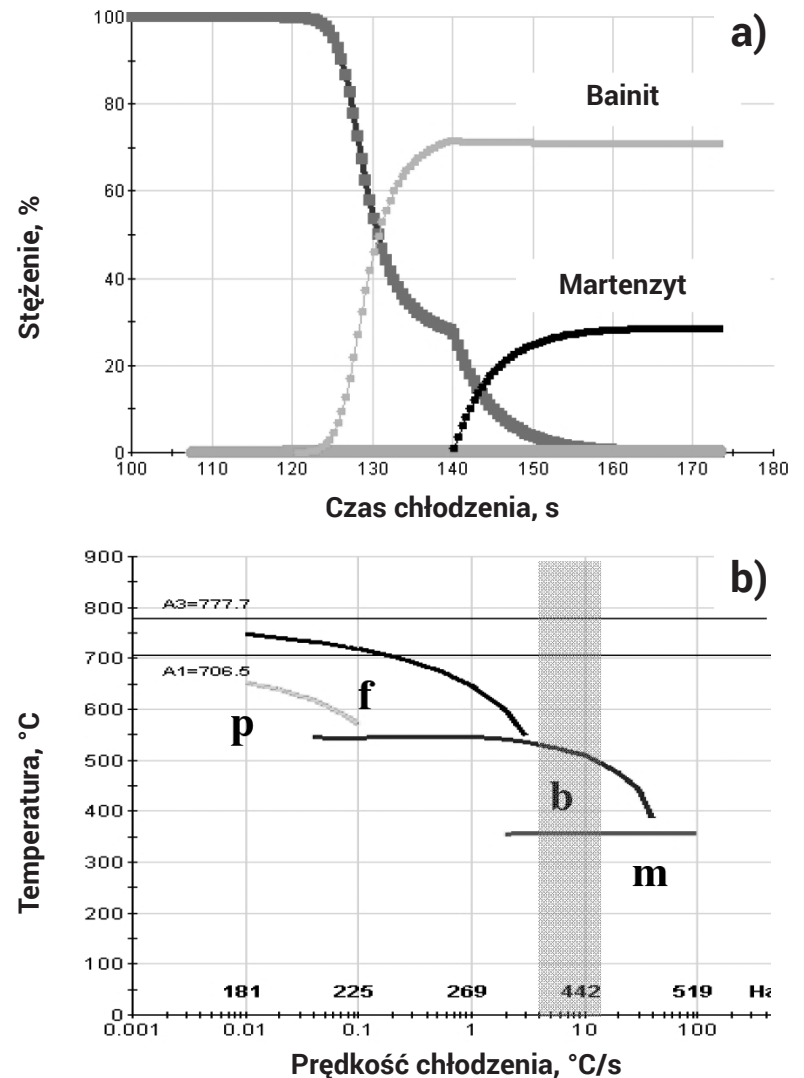

Rys. 5. Wyznaczenie właściwej prędkości chłodzenia SWC podczas spawania stali WELDOX 1300: a) kinetyka tworzenia faz w czasie, i b) zakres temperatury utworzenia faz (zaznaczony zakres właściwej prędkości chłodzenia)

Fig. 5. Determination of the optimal cooling rate during welding $H A Z$ metal steel WELDOX 1300 on: a) the kinetics of phase formation in time, and b) temperature range of phase formation (highlighted optimal cooling rates)

Analiza kinetyki rozpadu austenitu stali WELDOX 1300, oparta na próbkach badanych na symulatorze cykli cieplnych spawania w SWC (rys. 5), pozwoliła ustalić optymalną prędkość chłodzenia $\mathrm{V}_{6 / 5} \mathrm{z}$ punktu widzenia kształtowania struktury złącza spawanego. Z przeprowadzonych badań wynika, iż w celu otrzymania złącza spawanego o porównywalnej wytrzymałości materiału rodzimego i SWC na stali WELDOX 1300, koniecznie jest żeby prędkość chłodzenia $\mathrm{V}_{6 / 5}$ była na poziomie $6{ }^{\circ} \mathrm{C} / \mathrm{s}$, wartość ta znajduje się blisko prędkości chłodzenia zalecanej podczas spawania stali wysokowytrzymałej z granicą plastyczności powyżej 700 MPa, która według autorów [6] powinna zawierać się w przedziale $5 \leq \mathrm{V}_{6 / 5} \leq 20^{\circ} \mathrm{C} / \mathrm{s}$.

Należy podkreślić, że ze zwiększeniem prędkości chłodzenia rośnie ryzyko utworzenia zimnych pęknięć i kruchego pękania metalu SWC stali WELDOX 1300.

Wyniki badań symulacji zostały zweryfikowane podczas rzeczywistego procesu spawania. W celu uzyskania właściwej prędkości stygnięcia $\left(10 \div 20^{\circ} \mathrm{C} / \mathrm{s}\right)$ podczas spawania stali WELDOX 1300 były dobrane odpowiednie parametry
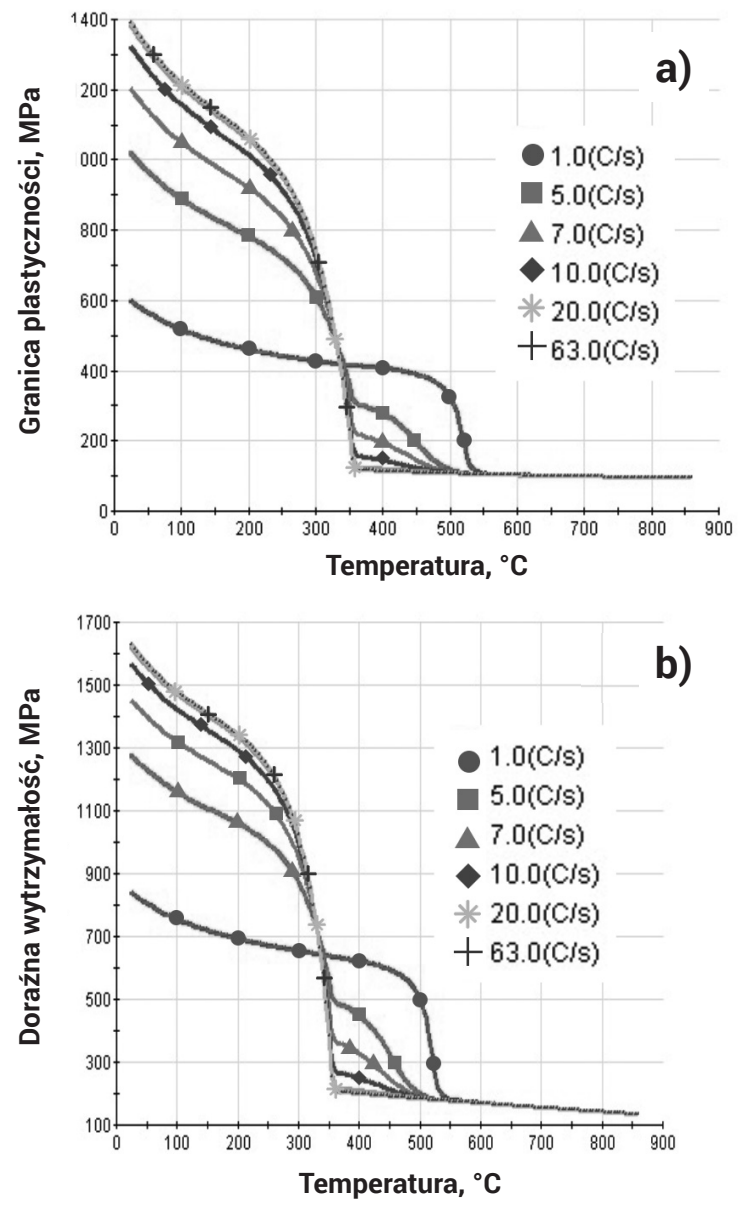

Rys. 6. Wpływ prędkości chłodzenia V8/5 na obliczoną wartość a) granicy plastyczności; b) doraźnej wytrzymałości na rozciąganie (obliczenia zgodnie z JMatPro)

Fig. 6. Effect the cooling rate V8/5 for the calculated values: a) the yield stress, b) the tensile strength (calculated JMatPro)

spawania: natężenie prądu spawania $\mathrm{I}_{\mathrm{s}}=250 \mathrm{~A}$, napięcie łuku $\mathrm{U}_{\mathrm{t}}=30 \mathrm{~V}, \mathrm{Vspaw}=0,23 \mathrm{~m} / \mathrm{min}$., temperatura wstępnego podgrzewania $120^{\circ} \mathrm{C}$.

Makrostruktura złącza spawanego stali WELDOX 1300 została przedstawiona na rysunku 7a. Badania pokazały, że pomimo podgrzewania wstępnego do temperatury $120^{\circ} \mathrm{C}$ w strefie ponownego nagrzania ciepłem przeciwległego ściegu powstają defekty, pęcherze i pęknięcia rysunku 7b., ta okoliczność wyjaśnia obniżenie plastyczności stopiwa (względem materiału rodzimego), względnego wydłużenia (do $3,7 \%$ ) i przewężenia (do 9,8\%), co jest cechą charakterystyczną złączy spawanych stali WELDOX 1300 przy spawaniu z podgrzewaniem do $120^{\circ} \mathrm{C}$ (tabl. II). Podczas prowadzenia opisanych badań zaobserwowano, że z pozoru nieznaczne zwiększenie temperatury wstępnego podgrzewania powyżej $150^{\circ} \mathrm{C}$ eliminuje obecność opisanych wcześniej wad i prowadzi do podwyższenia wytrzymałości (do $1050 \mathrm{MPa}$ ), wydłużenia względnego (do 13,3\%) oraz przewężenia tablicy II. (do 43,7\%). Stosunkowo niska udarność stopiwa jest przede wszystkim efektem braku na rynku właściwego spoiwa do spawania stali WELDOX 1300.

Utworzenie zimnych pęknięć w strefie ponownego nagrzania ściegów spoiny (rys. 7b), być może związane z: 1) procesami dyfuzji wodoru w SWC, o czym świadczy duża ilość pęcherzy (rys. 7b); 2) rozpuszczeniem faz węgliko-azotkowych $\left(\mathrm{Fe}_{3} \mathrm{C}, \mathrm{Ti}(\mathrm{C}, \mathrm{N}), \mathrm{Nb}(\mathrm{C}, \mathrm{N})\right)$ w strefach ponownego nagrzewania; 3) utworzeniem dużej ilości fazy mar-

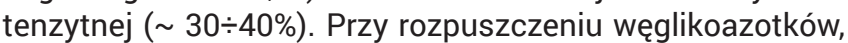
pierwiastki węglikotwórcze, przede wszystkim węgiel, przechodzą do roztworu stałego, zwiększają parametry sieciowe austenitu, przy późniejszym ochłodzeniu doprowadza do wzrostu lokalnego wewnętrznego naprężenia. 

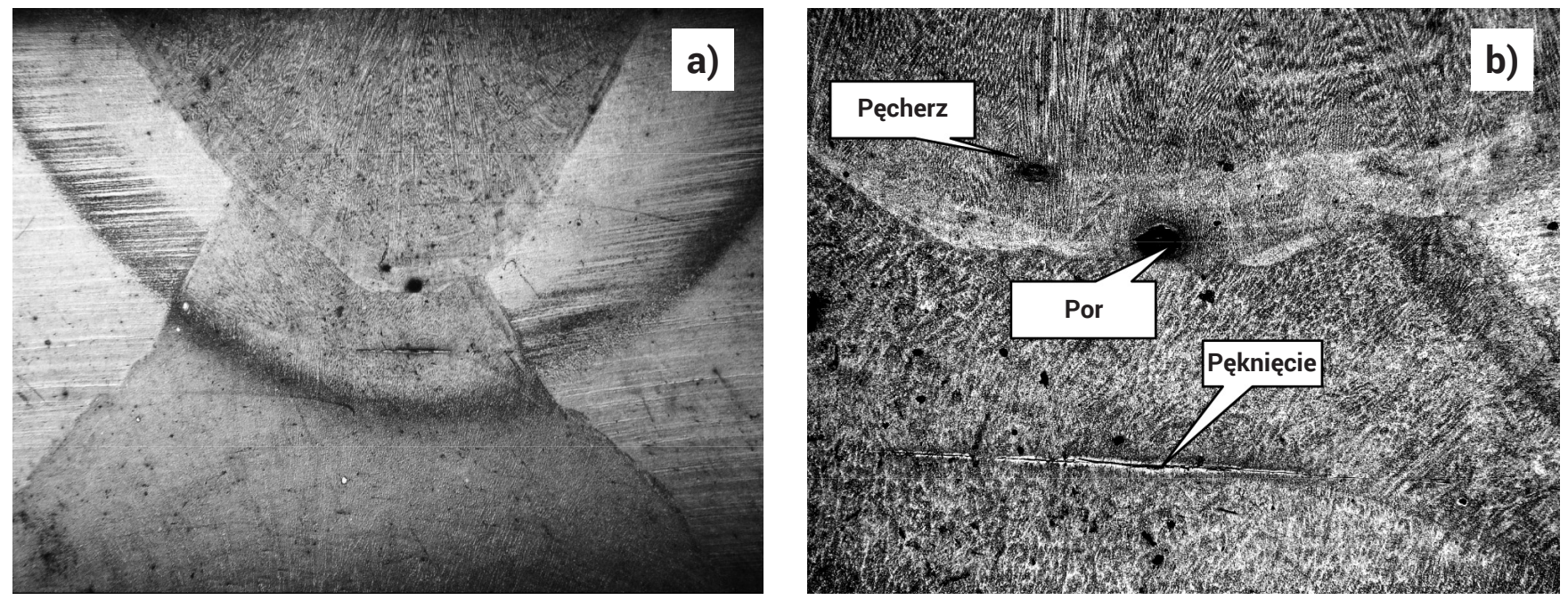

Rys. 7. Mikrostruktura złącza spawanego stali WELDOX 1300: a) ogólny widok, (x10); b) zimne pęknięcia i pęcherze w SWC (x50)

Fig. 7. Macroscopic weld steel WELDOX 1300: a) general view (x10), b) cold cracks and pores in the HAZ (x50)

\section{Wnioski}

Mikrostruktura materiału rodzimego wysokowytrzymałej stali WELDOX 1300 składa się zmieszaniny bainitno-martenzytnej ( $60 \%$ bainitu i 40\% martenzytu); bainityczna struktura zawiera dużą ilość drobnodyspersyjnych (50 $\div 100 \mathrm{~nm})$ ukierunkowanych igiełkowatych wydzieleń wenglikoazotków tytanu i węglików żelaza $\mathrm{Fe}_{3} \mathrm{C}$.

Zastosowanie symulacji cykli cieplnych spawania Gleeble 3800 pozwoliło ustalić, że wraz ze zwiększeniem prędkości chłodzenia z 1 do $63^{\circ} \mathrm{C} / \mathrm{s}$, temperatura końca przemiany martenzytycznej obniża się z $290{ }^{\circ} \mathrm{C}$ do $110^{\circ} \mathrm{C}$, co doprowadza do zwiększenia w SWC (stali WELDOX 1300) zawartości martenzytu od 35 do nawet 95\%.

W celu kształtowania optymalnej struktury bainitno-martenzytnej SWC, do spawanie stali WELDOX 1300 należy stosować wysokowytrzymały drut elektrodowy MEGAFIL 1100R, mający strukturę martenzytyczną, co w maksymalnym stopniu zabezpiecza jednolitą wytrzymałość połączenia spawanego.

W celu ograniczenia utworzenia zimnych pęknięć należy obniżać prędkość stygnięcia w SWC do $5 \div 6{ }^{\circ} \mathrm{C} / \mathrm{s}$, takie warunki można zapewnić przez wstępne podgrzewanie stali WELDOX 1300 do temperatury nie niżej $150^{\circ} \mathrm{C}$.

\section{Literatura}

[1] Welding Hardox $\AA$ and Weldox $\AA$ - http://www.ssab.com

[2] W. Ozgowicz , A. Kurc, G. Nawrat "Identification of precipitations in anodically dissolved high-strength microalloyed Weldox steels". Archives of Materials Science and Engineering, Vol. 31, No 2, s. 95-100, 2008.

[3] W. Ozgowicz, E. Kalinowska-Ozgowicz "Investigations on the impact strength of constructional high-strength Weldox steel at lowered temperature" Archives of Materials Science and Engineering, Vol. 32, No 2, s. $89-94,2008$.

[4] W. A.Kostin, G. M.Grigorenko, T. G. Solomijczuk, W. W.Zukow, T. A. Zuber, „Badania mikrostruktury szwów spawalniczych wysoko wytrzymalej stali konstrukcyjnej WELDOX 1300 z granicą wytrzymałości $1700 \mathrm{MPa}$ "Spawanie automatyczne, No 3, s.7-14, 2013.
[5] H. K. D. H. Bhadeshia "Bainite in Steels", Institute of Materials, London, s. 454, 1992

[6] S. L. Zdanow, L. I. Mokhoduj, P. A. Stryzak, Ju. M. Lebedjew, „Wpływ struktury stali wysokowytrzymalej 14KhG2SAFD na odporność na pełzanie" Spawanie automatyczne, No 3, s.9-12, 1992.

[7] Z. Guo, N. Saunders, J. P. Schillé, A. P. Miodownik "Material properties for process simulation", Materials Science and Engineering A, Vol. 499, s.7-13, 2009

[8] http://www.sentesoftware.co.uk/jmatpro.aspx 